\title{
Educational elements of instructional design to enhance the construction of virtual learning environments
}

\section{Elementos pedagógicos del diseño instruccional para potenciar la construcción de ambientes virtuales de aprendizaje}

\author{
URIBE-OLIVARES, Nadia Sarahi†*, SIORDIA-MEDINA, Paul Rafael and ZEA-VERDÍN, Aldo A.
}

Universidad Autónoma de Nayarit, Mexico.

ID $1^{\text {st }}$ Author: Nadia Sarahi, Uribe-Olivares

ID $1^{\text {st }}$ Co-author: Paul-Rafael, Siordia Medina

ID $2^{\text {nd }}$ Co-author: Aldo. A., Zea-Verdín

DOI: 10.35429/JCT.2020.13.4.1.7

Received: July 10, 2020; Accepted December 30, 2020

\begin{abstract}
From the perspective of experts in instructional design, what pedagogical elements favor the construction of virtual learning environments? It is the question that guides the present investigation. Education has had significant changes in recent decades, so institutions would be expected to transform. The management of educational change must be carried out from within the institutions themselves, who, through the operability of their educational model, foster the learning of their students. The innovation elements of an institution involve the entire educational community. The pedagogical foundations must permeate the management team, teachers and administrative staff to achieve true educational quality in any educational modality. This research focuses on the particularities of the virtual modality. It aims to analyze the different perspectives of instructional designers of institutions of higher and higher education regarding what pedagogical elements are necessary in offering virtual education. It also analyzes the professional profile of those who exercise the role of instructional designer in the different institutions.
\end{abstract}

Instructional, pedagogical, virtuality

\section{Resumen}

Desde la perspectiva de expertos en diseño instruccional ¿Qué elementos pedagógicos favorecen la construcción de ambientes virtuales de aprendizaje? Es la pregunta que guía la presente investigación. La educación ha tenido cambios significativos en las últimas décadas por lo que se esperaría que las instituciones se transformen. La gestión del cambio educativo debe de realizarse desde el interior de las propias instituciones, quienes a través de la operatividad de su modelo educativo propician el aprendizaje de sus estudiantes. Los elementos de innovación de una institución involucran a la totalidad de la comunidad educativa. Los fundamentos pedagógicos deben permear al equipo directivo, a los docentes y al personal administrativo para lograr una verdadera calidad educativa en cualquier modalidad educativa. La presente investigación centra su atención en las particularidades de la modalidad virtual. Tiene como objetivo analizar las diferentes perspectivas de diseñadores instruccionales de instituciones de educación superior y media superior respecto a qué elementos pedagógicos son necesarios en la ofrecer educación virtual. Asimismo, analiza el perfil profesional de quien ejerce el rol de diseñador instruccional en las diferentes instituciones.

Instruccional, pedagógicos, virtualidad

Citation: URIBE-OLIVARES, Nadia Sarahi, SIORDIA-MEDINA, Paul Rafael and ZEA-VERDÍN, Aldo. A. Educational elements of instructional design to enhance the construction of virtual learning environments. Journal Computer Technology. 2020. 4-13:1-7.

\footnotetext{
* Correspondence to Author (Email: nadia.uribe@uan.edu.mx)

$\dagger$ Researcher contributing as first author
} 


\section{Introduction}

Knowledge is ubiquitous, therefore teaching has to leave the classroom. Formal educational structures cannot respond to the needs of progressive adaptation in a world of change and growing demand in education. Education in nonschool modalities has had an important development. The current agreement 11/18/18 of the Ministry of Public Education (SEP) establishes the following definition:

It is characterized because the development of the teaching-learning process is carried out through an educational technology platform, electronic media or through autonomous learning processes and / or with didactic supports. The learning activities must reflect the use of the Educational Technology Platform or identify the suggested resources for autonomous learning processes (SEP, 2017).

In this sense, the depth of the process of social change that is currently taking place falls on those who assume responsibility for training the new generations (Aretio, Corbella and Figaredo, 2007). The new educational processes require the participation of various actors: teachers, administrators, researchers, designers, pedagogues. Who from different professional roles contribute to this transformation.

The transformation of the learning experience must be an experiential experience. The emergence of new roles within the training processes is necessary. It is not enough to incorporate educational technologies into institutions to achieve innovation in learning processes. Virtual education is nourished by inter and multidisciplinary work that is complemented and enriched with information and communication technologies (ICT) as well as emerging technologies.

Currently, $15 \%$ of people study through distance and online education (OECD, 2019). However, the quality of these programs raises concern, there are no longer established criteria for their evaluation and accreditation, at least in Mexico.
Virtual education has posed new challenges since it has a large number of different components than face-to-face education. The differences range, from the management of space and time to the resources with which the construction of knowledge is promoted. An essential component in virtual education is Instructional Design (DI) (Aretio, 2017).

ID is a distinctive pedagogical tool in this modality, which, in general, consists of a written plan that stipulates the content to be developed in a learning unit, what are the learning objects to use, how will the distribution of tasks and how the students will be organized.

In addition, it indicates the times in which the materials must be visible on a certain platform and when the work of the student body must be received. The general characteristics of instructional design have been studied since 1963 with the Dick and Carey Model. Its study has evolved in such a way that in recent decades models have emerged that allow us to analyze the importance of ID in teaching-learning processes.

\section{Virtual education as a dynamic process in universities}

The process of variation that educational institutions have faced is characterized around globalization, the knowledge society and postmodern organization (Colado, 2002). Faced with these social changes, institutions would be expected to transform. Educational institutions face the challenge and social responsibility of making educational changes that allow their community to adopt the most valued skills and abilities. Guzmán and Escudero (2016) point out that it is not enough to incorporate educational technology in institutions to achieve educational innovation, they point out that it is necessary for institutions to carry out optimal, controlled and reproducible transformations in order to promote and control the production processes of intangible capital in education.

The integration of information technologies and the constant demand towards bending physical limits and taking advantage of time generates new educational modalities. Educating the population through conventional means, meeting the multiple training demands of society, is practically unfeasible today.

URIBE-OLIVARES, Nadia Sarahi, SIORDIA-MEDINA, Paul Rafael and ZEA-VERDÍN, Aldo. A. Educational elements of instructional design to enhance the construction of virtual learning environments. Journal Computer Technology. 2020 
García (1999) expresses that classical institutions are not relevant for all the needs of those who require training. He points out the need to combine education and work in order to adapt, without having to abandon one or the other. It is visualized that this demand could be covered through the emergence of new educational modalities. Currently, virtual education has components or basic elements that are integrated into the processes to generate teaching-learning. García (1994) indicates that the classic structure of education in this modality is made up of the student, teacher, materials and communication channels and the organizational infrastructure.

For the institutions that offer education in an out-of-school modality, the instructional design in the educational field must facilitate the meaningful processing of information and learning; therefore, they must be able to teach knowledge in an organized manner (Merril, Li \& Jones, 1990).

Teaching at a distance encourages careful consideration of instruction in order to achieve an environment that facilitates learning. Martínez (2009) expresses that the role of instructional design in virtual education requires good planning. In general terms, planning means foreseeing goals to be achieved and making a project a reality, considering, of course, the means to achieve it.

Virtual education is taking advantage of face-to-face formats, however the analysis of its components is still not enough. According to Aretio, (2017) the studies carried out focus on verifying the effectiveness of distance systems, as well as the innovations and technologies that accompany digital learning, not the training processes in the modality itself.

Among the elements that have been analyzed in virtual education are established what summarizes the pedagogical-didactic part, the technical part and the follow-up of the course. It also indicates the analysis of the digital skills of the teachers who teach it and the technological infrastructure necessary for the modality.

\section{Pedagogical elements for virtuality: from the traditional didactic triad or virtual holistic models}

The education-technology binomial has to be insoluble at all times with regard to virtual education. Failure to reproduce face-to-face education processes should be a priority in the institutions that offer this modality. Respecting the characteristics of the population and the training processes of the students.

In recent decades, with the evolution of technologies, the behavior of society has undergone a modification, the most noticeable being the way in which communication processes are carried out. What is automatically related to changes in population training needs.

The evolution in the educational system is taken up from the proposal of Echevarría (cited by Aretio, Corbella and Figaredo, 2007) where a gradual change is established. These could be specified as: natural, urban and telematic; each one has been the result of the ideology of the moment and the technological advances put into practice.

In this sense, technological advances have caused a radical transformation in the way in which education is understood and developed. Therefore, it is necessary to establish the difference between two concepts that are often used synonymously: distance education and virtual education.

Distance education involves physical separation. The not necessarily coincide in time and space. That is, not a synchronous interaction in the same place between students and teachers. Arancibia and Montecino (2013).

The need to combine education with virtuality has modified the concept of teacher and student. It also transforms how the teachinglearning process is conceived. Which happens to not be something tangible but virtual. So it is related to new ways of acquiring knowledge, introducing the term eLearning. 
Virtual education has been the modality that from its birth has shown a greater predisposition to assume technological innovation (Aretio, Corbella and Figaredo, 2007). Therefore, the introduction of new information and communication technologies justify the development of new structures for training and knowledge acquisition.

Generating learning is one of the main challenges of education in any modality. Within virtual education there is the planning of its design for implementation on a platform. The incorporation of information and communication technologies in training processes in a formal and recognized way as an educational modality presents a challenge for institutions that take on the challenge of adding it to their educational offer (Alba, Carballo, Pons, Labra, Moreno and Rio, 2005).

Analyzing the development of a virtual environment supposes the knowledge of a methodology that gives foundation to the actions selected to carry out the achievement of the objective of the course. Martínez and Quincha (2012) mention that before the rise of information and communication technologies, it is necessary to modify the traditional schemes of design and planning of courses, therefore, thinking about recognizing pedagogical elements to facilitate the teaching processeslearning in virtuality leads to analyzing the different models that are used for the construction of virtual environments.

The 21st century society has expressed the need for new spaces for its educational processes. The use of the internet in education sets a standard to host these spaces. A Webbased educational system comments Mendoza and Galvis (1999) is not simply digitizing educational texts or making electronic books.

In this sense, the notion of designing courses in a non-face-to-face modality implies the awareness of identifying the environments where the learning process will be generated. In virtual education the concepts used to name these spaces are virtual learning environments (VLE).
A learning environment is the place where students and teachers converge to interact psychologically in relation to certain contents, using previously established methods and techniques with the intention of acquiring knowledge, developing skills, attitudes and in general, increasing some type of capacity. or competition (Enrique and Alzugaray, 2013).

Díaz-Barriga (2013) describes a learning environment as the result of establishing didactic sequences that offer an ordering of actions to be carried out, not necessarily in a unique way.

Another element considered important is interaction. Perrenoud (2012) expresses that the interaction is conceived as an exchange activity between the student's thinking and knowledge, between teachers and students through various exchanges, between each actor in education and an internal resource. Therefore, when talking about the environment, reference is made to a globalized whole, where spaces, objectives, knowledge and human beings establish relationships with a purpose, thus generating a fabric of interactions associated with the solution of needs that they require, every day with greater force, the creation of artificial structures by man to be achieved (Belloch, 2017).

In virtual education, it is necessary to establish theoretical foundations that guide practice and interactions. In this sense, constructivism is considered as a reference. For the constructivist model to be carried out, it is vitally important to emphasize collective work. In this way, generate debate and exchange of knowledge among the members of a group, share doubts and propose joint solutions, considering different points of view that can expand knowledge.

\section{Methodology}

The phenomenological-hermeneutical method is the axis through which the research is carried out. Phenomenological human science is the study of lived or existential meanings. Under this approach, the relationship of the perspectives of instructional designers will be explored in order to give meaning to the universe in which they develop. Van Manen (2003) expresses that phenomenological-hermeneutical research is a search for fulfillment, through explaining the world as it is. 
Therefore, it focuses on the description of the phenomenon as it is found in reality. From the experience and expressions of the participants. The interpretation of the results will be based on hermeneutics, which tries to understand the nature of the lived experience.

In order to know the reality from perspectives, the voices of ten instructional designers were taken, who based on their experience gave guidelines to generate a discourse of both national and international institutions.

Based on his discourse, he deconstructs educational reality in relation to the proposal of the traditional didactic triad, recognizing that virtual education has specific elements that it has to visualize to generate satisfactory teachinglearning processes.

\section{Results}

The pedagogical elements identified in the discourse of the participants of this research allow enriching this initial proposal with new elements typical of virtuality. For its construction, the macro categories and their respective codes were considered in order to have a graphic representation of the pedagogical elements to promote the construction of virtual learning environments.

Although the didactic triad is taken as a guiding figure, when analyzing the results obtained, a fourth vertex is integrated, where the instructional design is recognized as part of the learning process within the VLE.

The modification of the content vertex by learning object was carried out with the purpose of recognizing the set of digital resources where different activities, resources and functions are reflected to generate learning situations. Wiley (2000) expresses that a learning resource is "any digital resource that can be reused as a support for learning".

It is proposed that the four edges of the proposed diagram (learning objects, student, teacher and instructional design) act in a constant process of interaction.

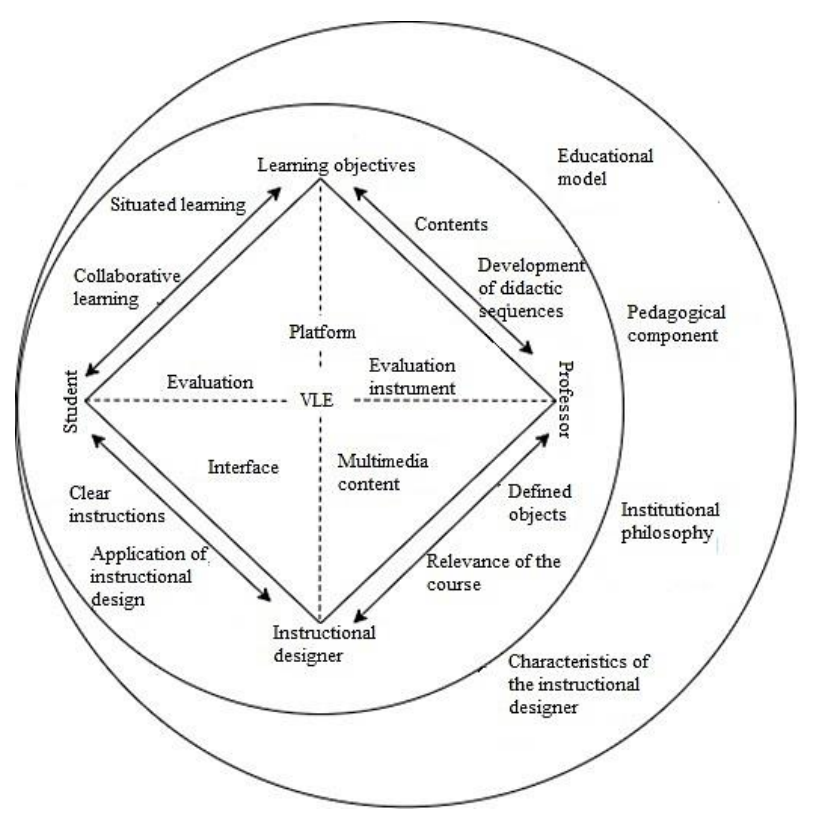

Figure 1 Holistic model for the virtual Uribe-Olivares

\section{Conclusions}

In conclusion and regarding the holistic model for virtuality, it explains the pedagogical elements, in the first circle the macro category educational model, pedagogical component, institutional philosophy and characteristics of the instructional designer are established. Recognizing the importance of the educational model within the institutions will allow influencing: institutional philosophy, pedagogical component and instructional design model, which are a frame of reference for the teaching-learning process.

Within the second circle, the actors considered within the teaching-learning process are established. In each of the vertices are the elements of the didactic triad; However, the limitation gave way to integrating a new vertex that is the instructional design since this determines the planning of the course, manages the technological resources, as well as implies the selection of the way in which the content is presented and the strategies so that the student can access it (Avilés and Avilés, 2002).

Within the same graph (figure 1) the pedagogical elements for learning are identified, depending on the relationship of each of the vertices. All based on the categories and codes found in the participating sample's discourse. 
Integrating the pedagogical elements found here to this new proposal of Diagram for virtual education facilitates understanding the needs that virtual education requires. It allows us to see that it is not possible to try to imitate the face-to-face education process on a platform.

\section{References}

Alba Pastor, C., Carballo Santaolalla, R., Estebanell Minguell, M., Pablos Pons, J. D., Paredes Labra, J., Ruiz Moreno, N., \& Zubillaga del Río, A. (2005). La viabilidad de las propuestas metodológicas para la aplicación del crédito europeo por parte del profesorado de las universidades españolas, vinculadas a la utilización de las TICs en la docencia y la investigación. Dirección general de Universidades e Investigación.

Aretio, L. G. (2017). Educación a distancia y virtual: calidad, disrupción, aprendizajes adaptativo y móvil. RIED. Revista Iberoamericana de Educación a Distancia, 20(2), 9-25.

Aretio, L. G., Corbella, M. R., \& Figaredo, D. D. (2007). De la educación a distancia a la educación virtual (p. 303). Ariel.

Belloch, C. (2017). Diseño instruccional.

Belmont, I. (1976). Principios éticos y directrices para la protección de sujetos humanos de investigación: Reporte de la Comisión Nacional para la Protección de Sujetos Humanos de Investigación Biomédica y de Comportamiento. Washington: Secretaría de Salud, Educación y Bienestar social. Recuperado de https://etsu. edu/irb/Belmont\% 20Report\% 20in\% 20Spanish. pdf.

Benoit, C. (2018). Competencia comunicativa en una actividad curricular de lenguaje con estudiantes chilenos de Pedagogía. Revista ESPACIOS, 39(46).

Berger, P. and Luckmann, T. (1967) The Social Construction of Reality. Harmondsworth: Penguin

Boneu, J. M. (2007). Plataformas abiertas de elearning para el soporte de contenidos educativos abiertos. RUSC. Universities and Knowledge Society Journal, 4(1), 36-47.
Brito, V. (2004), "El foro electrónico: una herramienta tecnológica para facilitar elaprendizaje colaborativo", Edutec. Revista Electrónica de Tecnología Educativa,núm. 17: http://www.uib.es/depart/gte/edutec-

e/revelec17/brito_16a.htm Fecha de consulta: $27 / 09 / 19$

Díaz Barriga Arceo, F. (2003). Cognición situada y estrategias para el aprendizaje significativo. Revista electrónica de investigación educativa, 5(2), 1-13.

Díaz Díaz, F., \& Castro Arévalo, A. L. (2017). Requerimientos pedagógicos para un ambiente virtual de aprendizaje. Cofin Habana, 11(1), 113.

Díaz-Barriga Ángel . (2013). TIC en el trabajo del aula. Impacto en la planeación didáctica. Revista iberoamericana de educación superior, 4(10), 3-21.

Enrique, C. M., \& Alzugaray, G. E. (2013). Modelo de Enseñanza-Aprendizaje para el Estudio de la Cinemática de un Volante Inercial usando Tecnologías de la Información y la Comunicación en un Laboratorio de Física. Formación universitaria, 6(1), 3-12.

García Aretio, L. (1994). Educación a distancia hoy.

García Aretio, L. (1999). Historia de la educación a distancia.

García Aretio, L. (2001). La educación a distancia: de la teoría a la práctica (No. C10 26). Ariel.

Martínez Poveda, M. P., \& Quincha Bejarano, É. P. (2012). Las tics (tecnologías de la información y comunicación) en el desarrollo del pensamiento creativo en los estudiantes del 6to y 7 mo año de Educación General Básica de la Escuela "24 de Mayo" parroquia Central, cantón San Miguel, provincia Bolívar en el año lectivo 2011-2012 (Bachelor's thesis, Universidad Estatal de Bolívar. Facultad de Ciencias de la Educación, Sociales, Filosóficas y Humanísticas. Escuela de Ciencias Básicas. Carrera de Educación Básica). 
Martínez Rizo, F. (2009). Evaluación formativa en aula y evaluación a gran escala: hacia un sistema más equilibrado. Revista electrónica de investigación educativa, 11(2), 1-18.

Mendoza, P., \& Galvis, A. (1999). Ambientes virtuales de aprendizaje: una metodología para su creación. Revista Informática Educativa, 12(2), 295-317.

Merril, M. D., Li, Z., \& Jones, M. K. (1990). Second Generation Instructional Design (ID2). Educational Technology, 2, 7-14.

Perrenoud, P. (2012). Cuando la escuela pretende preparar para la vida (Vol. 40). Graó. Secretaría de Educación Pública. (2017). Plan de estudios. Los doce principios pedagógicos. México 